\title{
Pricing to Market at firm level ${ }^{*}$
}

Lourdes Moreno Martín (Universidad Complutense de Madrid)

Diego Rodríguez Rodríguez (Universidad Complutense de Madrid and Fundación SEPI)

\begin{abstract}
:
This paper analyzes the influence of exchange rate variations on prices in foreign and home markets using firm data. The theoretical benchmark, based on the literature of Pricing to Market, also takes into account some hypotheses about the effects of demand variations and market power on prices. The empirical analysis for a Spanish economy points out the positive impact of the devaluations of the domestic currency on the relative evolution of prices, though smaller than obtained in previous evidence using aggregated data. The results also suggest a procyclical behavior of prices, which is positively affected by the degree of competition.

JEL Classification: F12, L60, L13
\end{abstract}

Key words: pricing to market, market dynamism, degree of competition

Diego Rodríguez Rodríguez

Fundación SEPI

C/ Quintana, 2, $3^{\text {a }}$ Planta

28008 Madrid - Spain

Tel.: +34-91-548 $8354 \quad$ Fax: +34-91-548 8359

E-mail: drodri@funep.es

* The paper has benefited from the suggestions of participants at the XVI Simposio de Análisis Económico in Alicante (Spain), V Encuentro de Economía Aplicada in Oviedo (Spain) and European Trade Study Group Conference in Kiel (Germany). This research has been partially funded by the projects SEC2000-0751 and SEC2000-0723. 


\section{Introduction}

Extensive literature from the eighties has been devoted to analyzing the effects of exchange rate variations on export prices. A general conclusion of those studies is the presence of an incomplete pass-through from exchange rate to prices, probably related to country size, as well as relevant industry differences. An extension of this literature has focused on the differences of exchange rate pass-through (EPT) to prices according to the destination market. It probably implies a destination specific adjustment of markups and, thereby, some degree of price discrimination across markets. That circumstance is referred to as Pricing to Market (PTM) strategy (Krugman, 1987).

There are several perspectives in the studies of PTM strategies. One of them is represented by the fixed-effects model of Knetter $(1989,1993)$, that analyzes differences in price variations across export markets. The goal is to condition the observed variations in export prices to the common changes in costs and margins, both unobservable, and approximated by a set of dummy variables: time and destination country effects. The relevant variations of prices are those based on markup variations specific for each market. The statistical contrast among several restrictions allows us to determine what kind of effects (industrial, source country or destination market) are the most relevant.

An alternative approach was proposed by Marston (1990). He identifies demand and cost conditions that generate different PTM elasticities, defined as changes in relative prices between foreign and home markets due to exchange rate variations. In this case the existence of PTM strategy is derived directly from regression and, therefore, it is not necessary to implement 
different restrictions on estimated parameters.

In both cases the empirical approach is based on industry-level analysis. In that context, given that prices probably refer to different products, it is difficult to confirm the existence of price discrimination across destination markets. It comes from the well known problem of the accuracy of export prices, given that they are approached by unit values in the majority of countries and, therefore, they have a composition-effect bias (Lipsey et al., 1991). Furthermore, the observed price differences across markets are probably also due to the distinct nature of firms. In that sense, Goldberg and Knetter (1997, p.1247) point out that "ideally, a test of Law of One Price would compose prices for two transactions in which the nationality of the buyers is the only difference in transaction characteristics. In practice, the identical goods assumption is almost surely violated to some degree in available data".

This paper address that criticism, extending the empirical approach of PTM literature, based on cross-industry analysis, to an empirical analysis based on firm data, following the Marston approach. The objective is to isolate those price variations across markets that are due to markup variations. Additionally, the empirical specification also considers some hypotheses about price flexibility proposed in industrial organization literature. This is convenient because there are other arguments apart from exchange rate variations, i.e. the effects of demand variations and the degree of market competition, which help to explain the observed differences in price variations across markets. The importance of analyzing prices across markets at firm level has been considered by Aw et al. (2001). Using firm-level unit values, they obtain important price differences between foreign and home markets for Taiwanese firms. 
The explanatory benchmark is applied to analyze the differences in price variations among foreign and home markets for Spanish firms over the period 1991 to 1999. This period was especially relevant for the European economies because of the changes experienced by the national currencies in the context of the turbulence of the European Monetary System (EMS). Specifically, the Spanish currency was devaluated in September and November 1992 (5\% and 6\%, respectively) and May 1993 (8\%). Finally, the peseta suffered a final devaluation of 5\% in May 1995. Furthermore, this period covers a complete cycle of the Spanish economy: the last years of the expansive period of the eighties, the fall in 1992-1993, and the recovery from 19941995.

The empirical results point out the existence of PTM strategy for Spanish export firms. It implies that changes in domestic currency have been used by firms to increase their relative (foreign/home) markups. Additionally, a procyclical behavior of both prices has been observed: market dynamism positively affects price variations. Furthermore, the degree of market competition conditions the transmission from demand fluctuations to prices.

The structure of this paper is as follows. Section 2 presents the theoretical benchmark to analyze the influence of the exchange rate and other explicative variables on relative (foreign/home) prices. In Section 3 the empirical specification is proposed. The data and the results of the econometric analysis are shown in Section 4. Finally, the main conclusions are summarized in Section 5. 


\section{Theoretical benchmark}

We assume a monopolistic competition framework, where products are differentiated and each firm has some degree of market power. Each firm produces in the home market and sells in two markets: the domestic market in which it sells at a price $\mathrm{P}_{\mathrm{t}}$, and the foreign market, where it sells at a price $Q_{t}$ in foreign currency. The firm faces home $h\left(P_{t}\right)$ and foreign $f\left(Q_{t}\right)$ demands with a joint cost function $C\left[\left(h\left(P_{t}\right)+f\left(Q_{t}\right)\right), z_{t}\right]$ where $\mathrm{z}_{\mathrm{t}}$ is the input cost in the domestic market. Furthermore, we assume that gray markets do not run, and therefore that market segmentation is effective (households cannot arbitrate). The profit function of the firm can be written as follows ${ }^{1}$ :

$$
\pi_{t}=P_{t} h\left(P_{t}\right)+e_{t} Q_{t} f\left(Q_{t}\right)-C_{t}\left[\left(h\left(P_{t}\right)+f\left(Q_{t}\right)\right), z_{t}\right]
$$

where $e_{t}$ is the exchange rate defined as home/foreign currency.

Maximizing the profit objective function, assuming that both prices are the decision variables and that the exchange rate is exogenous to the firm, we obtain the usual first order conditions:

$$
\begin{gathered}
P_{t}=C_{1} M\left(P_{t}\right) \\
e_{t} Q_{t}=C_{1} N\left(Q_{t}\right)
\end{gathered}
$$

where $\mathrm{C}_{1}$ is the marginal cost and $\mathrm{M}$ and $\mathrm{N}$ are the markups of the domestic and foreign price in domestic currency. Both of them can be expressed in terms of the price demand elasticities: $M(\cdot)=\frac{\eta}{\eta-1}$ and $N(\cdot)=\frac{\mu}{\mu-1}$ where $\eta$ and $\mu$ are home and foreign price demand elasticities. 
The effect of exchange rate variations on the foreign/home prices ratio in domestic currency is referred to as Pricing to Market elasticity $\left(\alpha_{1}\right)$, and can be written as:

$$
\alpha_{1}=\frac{\partial X_{t}}{\partial e_{t}} \frac{e_{t}}{X_{t}}=1+\beta_{1}-\beta_{2}
$$

where $X_{t}=\frac{e_{t} Q_{t}}{P_{t}}$ is the prices ratio, $\beta_{1} \quad\left(=\frac{e \partial Q}{Q \partial e}\right)$ is the exchange rate pass-through elasticity (EPT), which reflects the degree in which a variation of exchange rate is transmitted to export price in foreign currency $\mathrm{Q}_{\mathrm{t}}$. Export price in national currency is not affected by exchange rate changes when there is a complete EPT $\left(\beta_{1}=-1\right)$. The parameter $\beta_{2} \quad\left(=\frac{e \partial P}{P \partial e}\right)$ measures the effect of exchange rate variation on home price $\mathrm{P}_{\mathrm{t}}$. Therefore, PTM elasticity is here used as a wider concept that EPT, including the joint effect of exchange rate on relative prices, not merely on export price. As a result, if $\alpha_{1}$ is not equal to zero then relative prices vary when the exchange rate also does and, therefore, price discrimination between both markets would be observed.

The relative prices can also be expressed as a ratio of the markups $\left(X_{t}=\frac{N}{M}\right)$, since marginal costs are assumed to be identical for both markets. Then PTM elasticity can also be written as follows:

$$
\alpha_{1}=\frac{\partial X_{t}}{\partial e_{t}} \frac{e_{t}}{X_{t}}=\tau \beta_{1}-\delta \beta_{2}
$$

where $\delta$ and $\tau$ are the elasticities of home and foreign markups with respect to prices. The PTM elasticity $\left(\alpha_{1}\right)$ will be zero if both markups are constant ( $\tau$ and $\left.\delta=0\right)$. This happens when both demands have constant price elasticities $\left(\mu_{\mathrm{Q}}=0 \text { and } \eta_{\mathrm{P}}=0\right)^{2}$. However, this non price discrimination is compatible with an incomplete $\operatorname{EPT}\left(-1<\beta_{1}<0\right)$ if marginal costs are 
increasing. This indicates clearly that the effect of exchange rate prices on relative prices are only defined by the elasticities of margins ${ }^{3}$.

In a dynamic context with predetermined prices, a variation of relative prices $X_{t}$ can also reflect a surprise effect due to a non-anticipated variation of the exchange rate. Giovannini (1988), Marston (1990) and Kasa (1992) face this problem in distinct ways, obtaining in all cases evidence in favor of discriminatory pricing beyond such surprise effect. In this paper, this effect is not considered because we assume that the temporal period of observations to be used in the empirical analysis (annual data) is sufficiently wide to allow firms to vary their prices. In so doing we can, to some extent, avoid the influence of delayed response. Additionally, when prices are predetermined the decision about the invoice currency for exports is a strategic variable for firms (see Giovannini, 1988).

The price ratio $X_{t}$ can change not only due to exchange rate variations, but also price inputs variations $\left(Z_{t}\right)$, which is the second argument of the cost function. That price inputs variation could be due to an exchange rate fluctuation or any other reason. However, as with the exchange rate effect, the impact of the variation of the input cost depends on the markups elasticities. Specifically, it is proportional to the difference between the foreign and domestic markup elasticities: if both are identical $(\tau=\delta)$, a variation in inputs price will have no effect on relative prices ${ }^{4}$.

Though the exchange rate is probably an important variable to explain differential growth of prices across foreign and home markets, it is not the only one. Other effects linked to destination markets and industry characteristics may play a relevant role. Specifically, demand 
shocks may generate variations in relative prices. In that way, the previously mentioned home (foreign) demand could incorporate the effect of home (foreign) income. The income elasticities of demand would have an elaborated form, with a non predetermined effect on relative prices.

Nevertheless, we can consider the predictions about the effects of shifts in demand on changes in prices derived from industrial organization literature. There has been a great deal of discussion about the procyclical or countercyclical character of prices and markups. Though some studies (i.e., Rotemberg and Saloner, 1986) predict a countercyclical behavior, the majority of empirical evidence supports a procyclical relationship. One of the reasons pointed out is that more expansive demand facilitates collusive agreements (Haltinwanger and Harrington, 1991), independently of the geographical extent of the market (home or foreign).

Additionally, the transmission from demand shifts to prices may be affected by the degree of market competition. Phlips (1980) concludes that demand changes are transmitted less to prices in industries where there are more firms. That analysis was extended by Weiss (1994) considering the other dimension in the level of concentration: the effect of disparities in firm size. In that case he obtains a non linear effect of market concentration on the sensitivity of prices to demand and cost changes. In a more recent study, Ghosal (2000) concludes that positive demand shocks increase markups only in high concentration industries. These results agree with our previous reasoning with regard to the greater possibilities of achieving collusive agreements in expansive cycles.

On the other hand, the effect of exchange rate variations on export prices (and therefore on relative prices) may also be affected by the degree of market competition. If firms face more 
competition in foreign markets is expected less transmission of exchange rate pass through to export price in foreign currency. In the extreme, if export firms have price taker behavior EPT would be zero, and therefore PTM will be large. This is the kind of result found by Nagataki (2002), following Marston's approach, and Lee (1995). Similar arguments were proposed by Yang (1997). In the context of a Dixit-Stiglitz model, he found that pass through is larger the more differentiated the product in an industry. However, it should be noted that an opposite result is derived with Cournot conjectures and homogeneous product (Dornbush (1987), Lee (1997) and Menon (1996)). In that framework a more concentrated foreign market implies less EPT. Complementary results are showed in Feenstra et al. (1996). Using a Bertrand differentiated products model, they found that the relationship between EPT and market share is nonlinear and sensitive to assumptions about demand and firms interactions.

\section{Empirical specification}

A simple empirical specification can be derived from (1) and (2). Price variation in each market depends on two factors: changes in marginal costs $\left(\mathrm{C}_{\mathrm{it}}\right)$ and changes in home and foreign markups $\left(\mathrm{M}_{\mathrm{it}}\right.$ and $\mathrm{N}_{\mathrm{it}}$, respectively).

$$
\begin{gathered}
\Delta P_{i t}^{F}=\theta_{1}^{F} \Delta C_{i t}+\theta_{2}^{F} \Delta N_{i t}+\varepsilon_{i t}^{F} \\
\Delta P_{i t}^{H}=\theta_{1}^{H} \Delta C_{i t}+\theta_{2}^{H} \Delta M_{i t}+\varepsilon_{i t}^{H}
\end{gathered}
$$

where the $\mathrm{i}$ and $\mathrm{t}$ index firms and time, respectively, and $\mathrm{F}$ and $\mathrm{H}$ refer to foreign and home markets. Following the notation of the previous section $\Delta P_{i t}^{F}=\Delta e_{i t}+\Delta Q_{i t}$, where $P_{i t}^{F}$ is foreign price denominated in home currency and $P_{i t}^{H}$ is the home price. 
Our interest lies in analyzing the variation of relative prices. That variation is the difference between (3) and (4). The effects of changes in marginal costs on relative prices would disappear if $\theta_{1}^{F}=\theta_{1}^{H}$. It may be justified under the assumption of a joint cost function. It could be argued that products sold in both markets are affected by different costs, for example, sunk costs (i.e., costs linked to entry in foreign markets) or variable costs (i.e., transport costs). However, even in that case it would have small consequences given that empirical specification is in first differences. We would have to assume the presence of any type of supply shock having an effect only on a single market destination.

The empirical specification of the differences in price variation across markets is therefore mainly explained by the differences in changes in markups, considering the variables referred to in the previous section:

$$
\begin{aligned}
\Delta P_{i t}^{F}-\Delta P_{i t}^{H} & =\alpha_{1} \Delta e_{i t}+\gamma_{1}\left(\operatorname{com}_{i t}^{F} * \Delta e_{i t}\right)+\gamma_{2}^{F} \Delta d_{i t}^{F}+\gamma_{2}^{H} \Delta d_{i t}^{H}+\gamma_{3}^{F}\left(\Delta d_{i t}^{F} * \operatorname{com}_{i t}^{F}\right) \\
& +\gamma_{3}^{H}\left(\Delta d_{i t}^{H *} \operatorname{com}_{i t}^{H}\right)+\gamma_{4} \Delta Z_{i t}+u_{i t}
\end{aligned}
$$

where $\Delta e_{i t}$ is exchange rate variation, $\Delta \mathrm{d}_{\mathrm{it}}^{\mathrm{F}}\left(\Delta \mathrm{d}_{\mathrm{it}}^{\mathrm{H}}\right)$ is demand variation in foreign (home) markets, $\operatorname{com}_{\mathrm{it}}{ }^{\mathrm{F}}\left(\mathrm{com}_{\mathrm{it}}{ }^{\mathrm{H}}\right)$ is the degree of competition in foreign (home) markets, $\Delta \mathrm{Z}_{\mathrm{it}}$ is the cost variation, and $u_{i t}=\varepsilon_{i t}{ }^{\mathrm{F}}-\varepsilon_{i t}{ }^{\mathrm{H}}$.

Though the exchange rate is a macroeconomic variable exogenous to firms, we measure it at firm level considering the different export markets for each firm. The effect of this variable gets the PTM elasticity and we expect a positive sign $\left(\alpha_{1}>0\right)$. The growth of markets is also expected to have a positive effect on both prices. Therefore, the foreign (home) market 
dynamism is expected to have a positive (negative) sign on relative price variation $\left(\gamma_{2}^{F}>0\right.$ and $\left.\gamma_{2}^{H}<0\right)$. We also consider the effect that the degree of market competition could have on the impact of market dynamism on relative price variation. According to the previous hypotheses, the expected signs for the interacted variables are $\gamma_{3}^{F}<0$ and $\gamma_{3}^{H}>0$. With respect to the effect on the transmission of exchange rate variations, as we previously discussed, the theoretical results are not conclusive. However, in the context of Marston's model we expect a positive sign on PTM elasticity.

A clear advantage of (5) is that it eliminates fixed firm effects which are implicit in (3) and (4). Besides, this is independent of whether those idiosyncratic effects are observable or not; for example, unobservable quality and reputation (Allen, 1988). This is extensive to any other firm variable which does not have variability with respect to each market ${ }^{5}$. As Aw et al. (2001) point out, if there are relevant fixed firm effects $\left(\mu_{\mathrm{i}}\right)$, the error variance of (5) $\left(V\left(u_{i t}\right)=V\left(\varepsilon_{i t}^{E}-\varepsilon_{i t}^{N}\right)=2 \sigma_{\varepsilon}^{2}\right)$ will be smaller than error variance in (3) and (4) $\left(V\left(\mu_{i}+\varepsilon_{i t}\right)=\sigma_{\mu}^{2}+\sigma_{\varepsilon}^{2}\right)$. This implies a more precise estimate of the differences in prices across markets than estimates that use firms selling only in one of the two markets.

\section{Data and econometric results}

The sample is provided by the Survey on Business Strategies (SBS). This survey is carried out yearly by the Spanish Ministry of Science and Technology for about 2000 Spanish manufacturers (excluding the power generation plants and extractive companies). The population considered covers manufacturing firms with ten or more employees. All companies with over 
200 employees were asked to participate. A second category was made up of companies that employed between 10 and 200 workers, which were selected by a random sampling scheme according to NACE industry classification.

The surveyed firms give annual information about markets served, up to a maximum of five, identifying their relative importance (in percentage) in total sales of the firm. Each firm identifies the geographical limits and the price variation with respect to the previous year. The geographical limit is defined by three categories: a) home (local, provincial, regional and national), b) foreign and c) home-foreign. In 1991, 74\% of the firms defined the geographical limit of their markets as domestic. That proportion declined throughout the nineties, going along with the process of internationalization of Spanish firms. In 1999 almost $40 \%$ of firms declared that they had foreign markets.

Given that our main interest is to analyse price discrimination behavior, only those firms operating simultaneously in both markets (home and foreign) have been selected. Additionally, in order to assure that products sold in both markets by each firm are identical, only nondiversifying firms according to the 5-digit industrial classification have been selected ${ }^{6}$. The total number of observations for the period 1991-1999, after missing data for any variable have been removed, is 2346 .

As it shown in Table 1, the largest price variation occurs in 1994-1995, in coincidence with the recovery after the short crisis of the early nineties in European countries. It suggests a procyclical behavior of prices in both markets. In 1991-1994, 1996 and 1999 foreign prices $\left(\Delta P^{F}\right)$ rose more than home prices $\left(\Delta P^{H}\right)$. It is important to note that both prices are measured 
as growth rates, so we really do not know if a positive difference between both prices indicates a convergence or the opposite (see Appendix for variable definitions).

Additionally, about $40 \%$ of Spanish manufacturing firms vary prices in a different magnitude across home and foreign markets. However, for each firm, the relation between both price variations is very close. The correlation is over $86 \%$ for the period as a whole, and it is reduced to $74 \%$ when only firms varying prices in different proportions in both markets are considered. That relation can be seen in Figure 1, in which the main line indicates the nondiscriminating behaviour.

[Table 1] and [Figure 1]

An additional result that can be obtained from Figure 1 is the high dispersion of price variations among firms. Those differences are much higher than disparities in price variations between home and foreign markets for each firm. It emphasises that the use of industrial aggregated variations of prices hide the large heterogeneity among firms. Any test will accept that both price variation means are equal, given the high industrial variance. This result still holds even if a more des-aggregated industrial classification is employed. For example, Aw et al. (2001) also obtain high disparities for a sample of Taiwanese electronic firms with industries defined at seven digits.

Though this paper analyzes price discrimination across foreign and home markets, this behavior can also occur among domestic markets. However, the proportion of firms with distinct price variations between nation-wide markets and more reduced markets (local, provincial and 
regional) is smaller than the proportion obtained comparing home and foreign markets, and never reaches $30 \%$. This fact is in keeping with the evidence obtained by Engel and Rogers (1996) about the relevance of the border effect.

A possible criticism for using firm prices to infer price discrimination is linked to transfer pricing practices among plants (Rangan and Lawrence, 1993). However, given that production in foreign countries by Spanish firms is very reduced, export prices should not be biased by intrafirms transactions among home and subsidiary plants. In fact, more than $90 \%$ of the firms analyzed have only one industrial plant. Additionally, this makes it more likely that marginal costs associated to sales in domestic and foreign markets would be equal.

With respect to the explanatory variables of the empirical specification (see (5)), the nominal exchange rate variation has been elaborated for each firm using information about its export destinations. Specifically, it distinguishes among European Union countries, and the rest of OECD and non-OECD countries. That exchange rate has been elaborated in first differences, and a positive sign indicates a depreciation of home currency. The cost variation is measured by the evolution of labour costs by worker. The demand evolution in each market is approached by a dummy variable which indicates the degree of dynamism of demand according to three values: 1 (recessive market), 2 (stable market) and 3 (expansive market).

Finally, the degree of competition is approached by the market share (ms) of the firm. We assume that a larger market share implies less competition, and therefore an opposite sign is expected for this variable $\left(\gamma_{1}<0, \gamma_{3}^{F}>0, \gamma_{3}^{H}<0\right)$. 
Table 2 shows the average values of these variables. As expected, firms indicate a higher level of competition in foreign markets. It is important to emphasize that these variables have been elaborated with information provided by firms. It implies that such variables pick up the effect of the relevant competition for the firms, avoiding the classical problem of the relevant market that emerges with aggregate (industrial) information. In that sense, though Spain is usually considered as a small country in the context of international trade that assumption is not necessarily true at firm level. Each firm identifies its relevant market, so that the field of competition is more limited. That is the reason why the market shares are apparently large.

The equation (5) has been estimated by ordinary least squares, taking into account the usual assumptions in panel data methodology. Particularly, it has been supposed that error terms are independent among firms, but restrictions on autocovariances are not imposed for each firm. The results are shown in Table 3.

All the estimations include industrial dummies, and as the Wald test shows they are significantly different of zero. However, time effects are not included since they are highly multicolinear with exchange rate variations. That is because the exchange rate is a macroeconomic variable and the step effect that it introduces is statistically similar to time dummies. The only variability among firms in this variable is the result of the distinct weighting that each export market has in total exports for each firm. The results of a previous regression with only time effects as explanatory variables show significant differences in the variation of prices across foreign and home markets in the years 1992, 1993 and 1995. The devaluation of the domestic currency that happened in those years could have been an explanatory factor. 
In the first column the estimation only includes the exchange rate variations, foreign and home demand dynamism and cost evolution. A positive and significant effect of the exchange rate on relative prices can be observed. The estimated parameter reflects that a $10 \%$ devaluation of national currency raises the differential of prices between both markets by $0,37 \%$ This PTM elasticity is smaller than in previous studies with industrial data and implies a larger degree of exchange rate pass-through to export price in foreign currency.

[Table 3]

Additionally, it can be adduced that the estimated PTM elasticity reflects a long-term effect given that annual data are used. Probably in the short term, with monthly or quarterly data, the increase in export prices in home currency after a non-anticipated depreciation of national currency could be more relevant due to prefixed prices if export price is invoiced in foreign currency $^{7}$. As contracts are revised, it is more likely that national currency depreciation is passed through export price in foreign currency. We lack information about delivery lags with regard contract prices changes by Spanish firms, which is also the case in other countries ${ }^{8}$.

The small PTM elasticity is also in concordance with Gron and Swenson (1996), who point out that a smaller possibility to change production among plants in different countries is associated with a larger EPT. However, at the same time almost one third of the domestic firms are controlled by foreign multinationals. This could make different price discrimination behavior feasible among home and foreign owned firms. Complementary regressions considering the influence of foreign owning did not obtain significant results. It highlights the difficulty to 
explain the differences in price variation across firms departing from variables that do not distinguish among markets.

With respect to market dynamism, the estimated parameters present the expected signs. Prices present a procyclical behavior: an increase in demand generates positive price variations in both markets. Besides, the larger absolute value of the parameter associated to foreign demand dynamism which respect to home demand parameter suggests a bigger effect on foreign prices.

Column 2 presents the results also considering the degree of competition approached by the market share of firms. To consider that this variable could have a non-linear effect on the degree of transmission of exchange rate variations and market dynamism, interaction terms in quadratic form are also included. With respect to the interactions between exchange rate and the degree of competition, the obtained coefficients are non-significant. Therefore, there is no evidence about the influence of market power on PTM elasticity.

However, with respect to domestic market dynamism, the results are satisfactory with respect to previous hypothesis. The interaction between home demand evolution and the market share suggests that a larger market power allows for larger transmission of demand changes to prices in both markets. Besides, this relation is non-linear, in a way such that, given a change in the market dynamism, the positive effect on price variations decreases as market share increases. This result is in keeping with previous research, which suggests a concave relationship between market power and the degree of transmission of changes in demand to prices (Weiss, 1994). For foreign markets, the results also show a positive impact of market share on the transmission of demand dynamism but the estimated parameters are non-significant. 
The results also show that in any case there is a significant effect of cost variation on relative prices. It suggests that changes in costs are transmitted in the same magnitude to domestic and foreign prices or, alternatively, that if there were differences they are absorbed by adjustments in margins.

An additional explanation for the small PTM elasticity estimated could be that exchange rate variations are very small in several years of the period 1991-1999. It seems reasonable to think that the PTM strategy, which implies price stabilisation in foreign markets, is more probable when relevant exchange rate variations are produced. In the last years of the period, 1997-1999, the fulfilling of convergence requirements to enter the third phase of European Monetary Union implied the stability of domestic currency with respect to the other members. To evaluate this hypothesis we have repeated the estimations for the reduced period 1993-1995, when the domestic currency was strongly devaluated. They are shown in columns 3 and 4 of Table 3. As can be seen, PTM elasticity is substantially larger. A home currency depreciation of $10 \%$ implies in this period an increase in the relative prices of about $1,2 \%$. Therefore, it seems that Spanish export firms used the devaluations that occurred in the turbulent period of the European Monetary System to increase margins in foreign markets.

As in previous estimates, there is no significant effect of the degree of competition on PTM elasticity. With respect to market dynamism, the results obtained also confirm the theoretical hypothesis: demand evolution positively affects price variations and this effect is bigger for firms that have a larger market share. In this case the parameters associated to the interaction between foreign dynamism and market share are significant at $90 \%$. 


\section{V.- Conclusions}

This paper helps to fill the relative void of works done with firm data in PTM literature. The main goal has been to evaluate the effect of exchange rate variations on price discriminating behavior across foreign and home markets. However, the effect of other factors proposed in the context of Industrial Economics on relative price variations has also been considered.

Though the dependent variable is the same proposed by Marston (1990), the empirical approach adopted in this paper is similar to the Knetter model, where price variations related with changes in markups specific by destination market are identified. In this paper, the availability of a data set which distinguishes between price variations in home and foreign markets for each firm also allows us to isolate those variables, such as marginal costs, which affect both prices in a similar way. Therefore, only those effects related with specific market variables are considered.

The PTM elasticity obtained for the period 1991-1999 is smaller than obtained in other studies using industrial data (Marston, 1990; Nagataki, 2002). This result is not surprising for a small open economy such as Spain where large EPT, though incomplete, is expected (Menon, 1995). Furthermore, the large PTM obtained in previous empirical works could be influenced by the difficulties to control the effect of non-expected exchange rate variation on relative prices when export prices are prefixed in foreign currency. The data frequency used in this paper, annual data, surely reduces that problem. Additionally, given the nature of the European Monetary System, the probability that firms would perceive the 
exchange rate variation as a temporary change should be small. Then, firms had lesser incentives to delay their response after domestic currency depreciation. It implied a larger EPT and, therefore, a lesser effect of exchange rate variation on relative prices. Additionally, the low PTM elasticity found in this paper is in accordance with recent evidence by Campa and Goldberg (2002), who obtain than over the long run the pass-through elasticity is closer to one for most of the OECD countries, implying a prevalence of producer-currency pricing versus local-currency pricing.

Our results also point out the influence of other variables on relative prices. Specifically, market dynamism positively affects price variations in both markets. Besides, this effect is conditioned by the firm market share in a non-linear way. However, non significant evidence is obtained with respect to the effect of the degree of competition on PTM elasticity.

Contrary to the results obtained by Aw et al. (2001), changes in the tariff barriers and other trade restrictions should not have exerted an influence on the evidence obtained. The removal of trade barriers with other EU countries had almost been completed in 1990. Besides, though the implementation of the Single European Market from 1987 to 1993 eliminated nontariff trade barriers among European countries, the effect on prices in home and foreign markets should be similar.

Finally, though available data do not let us to analyze the post-Euro launching period, previous results are useful to raise some hypotheses about foreseeable effects of the single currency on prices. Specifically, the small effect of exchange rate variations in terms of relative prices across export and domestic markets in the nineties, beyond turmoil period, suggests that 
Euro launching would not have large negative consequences in relative profits associated to sales in domestic and export markets. Of course, it is compatible with potential loss of competitiveness associated to larger domestic price growth. However, the previous analysis remarks than much more relevant consequences would come from differences in cycle business across countries. As results also suggest, a more specific evaluation requires a better knowledge about specific market competition conditions across countries. 


\section{Appendix: Variable definitions}

$\Delta P^{H}$ and $\Delta P^{F}$ (Domestic and foreign variations prices): The surveyed firms give annual information about markets served (up to five), identifying their relative importance (in percentage) in total sales of the firm. Additionally, each firm identifies the geographical area (home, foreign and home-foreign) and the variation of price with respect to the previous year. Price variations for domestic and foreign markets have been elaborated using the proportions of sales with respect to total sales as weighting. When firms define the market as home/foreign, the price variation has been assigned to both destinations.

$d^{H}$ and $d^{F}$ (Individual indicator of the business cycle in the domestic and foreign markets): In the ESEE survey, each firm identifies the behavior of market demand during one year with respect to the previous years according to three different categories: recession, stability and expansion. A value of 1,2 and 3 is assigned respectively to each category. The domestic and foreign indices are constructed by weighting the previous values over all domestic and foreign markets defined by each firm. The weights are the proportion of sales in each market with respect to total sales.

$m s^{H}$ and $m s^{F}$ (Domestic and foreign market share): This variable has been elaborated by weighting the share of each market given by the firm in the same way as used previously for price variations and market dynamism. A zero value is assigned when the firm answers that its share is non-significant in a specific market. 
$e$ (Nominal exchange rate variation): Firms distinguish three export destiny: the European Union, the rest of the OCDE and the rest of the world. An individual nominal exchange rate has been calculated by weighting the Spanish nominal exchange rate with respect to these areas. The weights are the proportion of exports sold in each area with respect to total exports. Nominal exchange rates (peseta/foreign currencies of EU and peseta/ foreign currencies of OECD) are elaborated by the Bank of Spain following standard practices.

$z$ (Cost): Labor cost divided by the average workers of the firm during the year. 


\section{References:}

Allen, F. (1988): "A Theory of Price Rigidities when Quality is Unobservable", Review of Economic Studies 55: 139-151.

Athukorale, P. and J. Menon (1994): "Pricing to market behaviour and exchange rate passthrough in Japanese exports", The Economic Journal 104: 271-281.

Aw, B.Y., G. Batra and M. J. Roberts (2001): "Firm Heterogeneity and Export-Domestic Price Differentials: A Study of Taiwanese Electronics Products", Journal of International Economics, 54: 149-169.

Campa, J.M. and L. Goldberg (2002): "Exchange Rate Pass-Through into Import Prices: A Macro or Micro Phenomenon?”, Staff Reports 149, Federal Reserve Bank of New York.

Dornbush, R. (1987): "Exchange Rates and Prices", American Economic Review 77: 93-106.

Engel, C. and J. H. Rogers (1996): "How wide is the border?", American Economic Review 86: $1112-1125$.

Feenstra, R.C., J. E. Gagnon and M. Knetter (1996): "Market share and exchange rate passthrough in world automobile trade", Journal of International Economics 40: 187-207.

Gagnon, J. E. and M. Knetter (1994): "Pricing to market in international trade: Evidence from 
panel data on automobiles", Journal of International Money and Finance 14: 289-310.

Ghosal, V. (2000): "Product market competition and the industry price-cost markup fluctuations: Role of energy price and monetary changes", International Journal of Industrial Organization 18(3): 415-444.

Giovannini, A. (1988): "Exchange rate and traded good prices", Journal of International Economics 24: 45-68.

Goldberg, P. K. and M. Knetter (1997): "Goods Prices and Exchange Rates: What Have We Learned?", Journal of Economic Literature 35: 1243-1272.

Gron, A. and D. L. Swenson (1996): "Incomplete Exchange-Rate Pass Through and Imperfect Competition: The Effect of Local Production", American Economic Review 86: 71-76.

Haltinwanger, J. and J. E. Harrington (1991):"The impact of cyclical demand movements on collusive behavior", RAND Journal of Economics 22: 89-106

Kasa, K. (1992): "Adjustment costs and pricing-to-market. Theory and evidence", Journal of International Economics 32: 1-30.

Kim, Y. (1990): "Exchange Rates and Import Prices in the United States: A Varying Parameter Estimation of Exchange-Rate Pass-Through", Journal of Busines \& Economic Statistics 8: 305-314. 
Knetter, M. (1989): "Price discrimination by U.S. and German exporters", American Economic Review 79: 198-210.

Knetter, M. (1993): "The international comparison of price-to-market behavior", American Economic Review 83: 473-486.

Krugman, P. (1987): "Pricing to market when the exchange rate changes", in S.W. Arndt and J.D. Richardson (eds.), Real-financial linkages among open economies, MIT Press, Cambridge.

Lee, J. (1995): "Pricing-to-Market in Korean manufacturing exports", International Economic Journal 9: 1-12.

Lee, J. (1997): "The response of exchange rate pass-through to market concentration in a small economy: the evidence from Korea", The Review of Economics and Statistics 79: 142145.

Lipsey, R.E., L. Molinari and I.B. Kravis (1991): "Measures of Prices and Prices Competitiviness in International Trade in Manufactured Goods", in Peter Hooper and J. David Richardson (eds.), International Economics Transactions, Issues in Measurement and Empirical Research, University of Chicago Press: 144-195

Marston, R. (1990): "Pricing to market in Japanese manufacturing", Journal of International 
Economics 29: 217-236.

Menon, J. (1995): "Exchange rates and import prices for a small open economy", Applied Economics 27: 297-301.

Menon, J. (1996): "The degree of the determinants of exchange rate pass-through: market structure, no-tariff barriers and multinational corporations", The Economic Journal 106: 434-444.

Merino, F. and D. Rodríguez (1997): “A consistent analysis of diversification with nonobservable firm effects", Strategic Management Journal 18(9): 733-744.

Nagataki, Y. (2002): "Pricing-to-Market Behavior: Japanese Exports to the US, Asian and the EU', Review of International Economics 10(1): 140-150.

Phlips, L. (1980): "Intertemporal Price Discrimination and Sticky Prices", The Quarterly Journal of Economics 95: 525-542.

Rangan, S., R. Z. Lawrence and R. N. Cooper (1993): "The Responses of U.S. Firms to Exchange Rate Fluctuations: Piercing the Corporate Veil", Brookings Papers on Economic Activity 2: 341-369.

Rotemberg, J. and G. Saloner (1986): “A supergame-theoretic model of price wars during booms", American Economic Review 70: 390-407. 
Weiss, C. R. (1994): "Market Structure and Pricing Behaviour in Austrian Manufacturing", in K. Aiginger and J. Finsinger (eds.): Applied Industrial Organization: 187-203.

Yang (1997) Completar 
Table 1: Price variations by markets (1991-1999)

\begin{tabular}{ccccc}
\hline \hline & $\begin{array}{c}\text { Number of } \\
\text { firms }\end{array}$ & $\begin{array}{c}\text { Percentage of firms } \\
\text { with } \\
\Delta \mathbf{P}^{\mathrm{F}} \neq \Delta \mathbf{P}^{\mathbf{H}}\end{array}$ & $\Delta \mathbf{P}^{\mathbf{F}}$ & \multicolumn{2}{c}{ Average variation price by } \\
market & & $\Delta \mathbf{P}^{\mathbf{H}}$ \\
$\mathbf{1 9 9 1}$ & 222 & 46.3 & 1.56 & 1.46 \\
$\mathbf{1 9 9 2}$ & 259 & 48.6 & 0.60 & 0.23 \\
$\mathbf{1 9 9 3}$ & 236 & 40.7 & 1.64 & 1.35 \\
$\mathbf{1 9 9 4}$ & 233 & 43.3 & 4.68 & 4.47 \\
$\mathbf{1 9 9 5}$ & 245 & 41.6 & 3.70 & 4.32 \\
$\mathbf{1 9 9 6}$ & 251 & 41.0 & 1.07 & 1.00 \\
$\mathbf{1 9 9 7}$ & 280 & 42.5 & 1.40 & 1.41 \\
$\mathbf{1 9 9 8}$ & 320 & 38.4 & 0.12 & 0.34 \\
$\mathbf{1 9 9 9}$ & 300 & 32.0 & 0.44 & 0.35 \\
\hline $\mathbf{1 0 t a l}$ & 2346 & 41.3 & 1.58 & 1.54 \\
\hline
\end{tabular}


Table 2: Average values of market dynamism and market share (1991-1999)

\begin{tabular}{lccc}
\hline \hline & Domestic & Foreign & $\begin{array}{c}\text { Percentage of firms with } \\
\text { equal values in both markets }\end{array}$ \\
\cline { 2 - 4 } Markets dynamism & 2.03 & 2.15 & $39.3 \%$ \\
Market share & 17.88 & 8.67 & $36.0 \%$ \\
\hline \hline
\end{tabular}


Table 3: Differences in price variations across markets: foreign-home (1991-1999)

\begin{tabular}{|c|c|c|c|c|}
\hline & \multicolumn{2}{|c|}{ 1991-1999 } & \multicolumn{2}{|c|}{ 1993-1995 } \\
\hline & 1 & 2 & 3 & 4 \\
\hline$\Delta \mathrm{e}$ & 0.037 & 0.041 & 0.112 & 0.127 \\
\hline & $(1.9)^{\mathrm{a}}$ & $(1.7)$ & (3.7) & $(3.5)$ \\
\hline$\Delta \mathrm{e} \times \mathrm{ms}^{\mathrm{F}}$ & - & $\begin{array}{c}-0.056 \\
(0.3)\end{array}$ & - & $\begin{array}{c}-0.260 \\
(0.8)\end{array}$ \\
\hline$\Delta \mathrm{e} x\left(\mathrm{~ms}^{\mathrm{F}}\right)^{2}$ & - & $\begin{array}{c}0.002 \\
(0,1)\end{array}$ & - & $\begin{array}{c}0.259 \\
(0.7)\end{array}$ \\
\hline$\Delta \mathrm{d}^{\mathrm{F}}$ & $\begin{array}{c}0.454 \\
(3.6)\end{array}$ & $\begin{array}{l}0.444 \\
(3.5)\end{array}$ & $\begin{array}{c}0.644 \\
(2.7)\end{array}$ & $\begin{array}{c}0.572 \\
(2.4)\end{array}$ \\
\hline$\Delta \mathrm{d}^{\mathrm{F}} \mathrm{x} \mathrm{ms}^{\mathrm{F}}$ & - & $\begin{array}{l}0.621 \\
(1.1)\end{array}$ & - & $\begin{array}{c}2.095 \\
(1.8)\end{array}$ \\
\hline$\Delta \mathrm{d}^{\mathrm{F}} \mathrm{x}\left(\mathrm{ms}^{\mathrm{F}}\right)^{2}$ & - & $\begin{array}{l}-1.02 \\
(1.2)\end{array}$ & - & $\begin{array}{c}-2.649 \\
(1.8)\end{array}$ \\
\hline$\Delta \mathrm{d}^{\mathrm{H}}$ & $\begin{array}{c}-0.359 \\
(2.7)\end{array}$ & $\begin{array}{c}-0.287 \\
(2.2)\end{array}$ & $\begin{array}{c}-0.264 \\
(1.0)\end{array}$ & $\begin{array}{c}-0.132 \\
(0.5)\end{array}$ \\
\hline$\Delta \mathrm{d}^{\mathrm{H}} \mathrm{x} \mathrm{ms}^{\mathrm{H}}$ & - & $\begin{array}{c}-1.135 \\
(2.2)\end{array}$ & - & $\begin{array}{c}-1.619 \\
(2.0)\end{array}$ \\
\hline$\Delta \mathrm{d}^{\mathrm{H}} \mathrm{x}\left(\mathrm{ms}^{\mathrm{H}}\right)^{2}$ & - & $\begin{array}{l}1.572 \\
(1.9)\end{array}$ & - & $\begin{array}{l}1.904 \\
(2.0)\end{array}$ \\
\hline$\Delta \mathrm{z}$ & $\begin{array}{c}0.003 \\
(0.6) \\
\end{array}$ & $\begin{array}{l}0.003 \\
(0.6)\end{array}$ & $\begin{array}{c}0.004 \\
(0.3)\end{array}$ & $\begin{array}{r}0.003 \\
(0.3) \\
\end{array}$ \\
\hline $\begin{array}{l}\text { Number of } \\
\text { Observations }\end{array}$ & 2346 & 2346 & 714 & 714 \\
\hline Industrial effects ${ }^{b}$ & 35.3 & 38.8 & 44.5 & 44.9 \\
\hline
\end{tabular}

Notes:

a: t-ratios robust to heterocedasticity in parentheses.

b: Joint significance of industrial effects is calculated with a Wald test robust to heterocedasticity, distributed as $\chi^{2}(20)$. 
Figure 1: Foreign and home price variations (1991-1999)

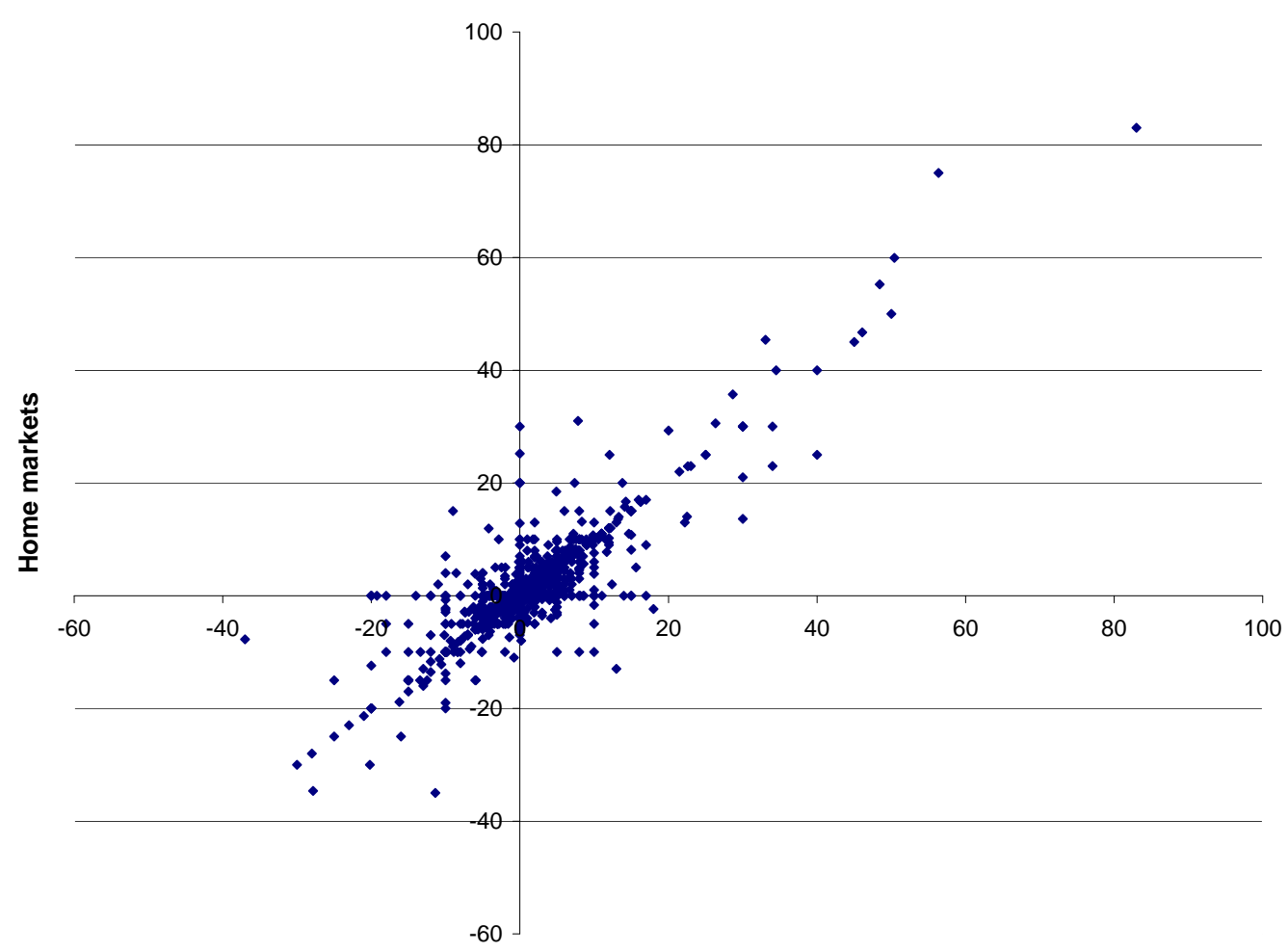

Foreign markets 
Notes:

${ }^{1}$ We follow Marston (1990).

${ }^{2}$ The markups elasticities can be expressed in terms of the price elasticity of demands: $\tau=-\mu_{\mathrm{Q}} \mathrm{Q} /(\mu-1) \mu$ and $\delta=-\eta_{\mathrm{P}} \mathrm{P} /(\eta-1) \eta$.

${ }^{3}$ An alternative approach, not based on the convexity of demand schedules, is due to Kasa (1992), who analyzes price discrimination across export markets based on differences in adjustment costs.

${ }^{4}$ If our interest was to model export prices, we would have to take into account that a depreciation of national currency makes imported inputs more expensive. With industrial data, Athurokala and Menon (1994) propose a simultaneous estimation of export price and cost functions.

${ }^{5}$ This reasoning is not extensive if the firm effects vary across markets. For example, if the reputation of the firm perceived by consumers depends on the character of the market (domestic or export). It is known that reputation can reduce price demand elasticity.

${ }^{6}$ An analysis of diversification with this survey can be seen in Merino and Rodríguez (1997). ${ }^{7}$ According to the Bank of Spain, 55\% of Spanish exports of products were invoiced in foreign currency in 1991. This percentage was one of the largest in EU and was similar to Japan (Marston, 1990).

${ }^{8} \mathrm{Kim}$ (1990) is one of the few authors who uses delivery lags to link observed prices with contract prices. 